\title{
PENGEMBANGAN MEDIA KOSIR UNTUK MENINGKATKAN MOTIVASI BELAJAR SISWA KELAS V SD
}

\author{
Devi Indah Sari ${ }^{1}$, Yulia Eka Yanti ${ }^{2}$ \\ 1,2 PGSD Universitas Islam Raden Rahmat Malang \\ 1deviindahsari709@yahoo.com \\ 2yulia.ekay@uniramalang.ac.id,
}

\begin{abstract}
The development of the KOSIR (Water Cycle Box) media was carried out because students still had difficulty sequencing the process of the water cycle and there was still a lack of media used in learning which caused student motivation in $5^{\text {th }}$ Grade of Elementary School was still quite low. This research aims to produce learning media KOSIR (Water Cycle Box) that is feasible and valid for use in learning science material, as well as for increase students motivation through the implementation of KOSIR learning media (Water Cycle Box). In this research and development, researcher used the $\mathrm{RnD}$ (Research and Development) type of research developed by Borg and Gall. The results showed motivation also increased, this can be seen from the results of the questionnaire on student learning motivation in the main field test before using the media obtained $52 \%$, after using conventional media KOSIR (Water Cycle Box) students obtained 92\%. In the questionnaire results, the percentage of each indicator was calculated. It is said that student motivation is high and increased by $40 \%$ after being given KOSIR media (Water Cycle Box).
\end{abstract}

Keywords: Learning Media, KOSIR, learning motivation

\begin{abstract}
ABSTRAK
Pengembangan media KOSIR (Kotak Siklus Air) ini dilakukan karena siswa masih kesulitan dalam mengurutkan proses terjadinya siklus air dan masih kurangnya media yang digunakan dalam pembelajaran yang menyebabkan motivasi siswa pada kelas V SD masih cukup rendah. Penelitian ini bertujuan untuk menghasilkan media pembelajaran KOSIR (Kotak Siklus Air) yang layak dan valid digunakan dalam pembelajaran materi IPA, serta untuk meningkatkan motivasi belajar siswa melalui implementasi media pembelajaran KOSIR (Kotak Siklus Air). Pada penelitian dan pengembangan ini, peneliti menggunakan jenis penelitian $\mathrm{RnD}$ (Research and Development) yang dikembangkan oleh Borg and Gall. Hasil penelitian menunjukkan bahwa motivasi belajar siswa juga meningkat, hal ini dapat dilihat dari hasil angket motivasi belajar siswa pada uji lapangan utama sebelum menggunakan media diperoleh $52 \%$, sesudah menggunakan media KOSIR (Kotak Siklus Air) siswa memperoleh $92 \%$. Hal ini dikatakan bahwa motivasi belajar siswa tinggi dan meningkat sebesar $40 \%$ setelah diberikan media KOSIR (Kotak Siklus Air)
\end{abstract}

Kata Kunci: Media Pembelajaran, KOSIR, motivasi belajar 


\section{A. Pendahuluan}

IPA atau sains merupakan ilmu pengetahuan yang mempelajari mengenai alam semesta beserta isinya, serta peristiwa-peristiwa yang terjadi didalamnya yang dikembangkan oleh para ahli bersadarkan proses ilmiah (Sudjana, 2013:15). Menurut Muslichah (2006:23), pada dasarnya pembelajaran IPA di sekolah dasar bertujuan untuk menanamkan rasa ingin tahu dan sikap positif peserta didik terhadap sains teknologi masyarakat, mengembangkan ketrampilan proses untuk mengamati lingkungan sekitar, menemukan permasalahan, memecahkan masalah dan membuat keputusan sehingga siswa dapat berfikir kritis dan objektif. Oleh karena itu, dalam mempelajari IPA sangat dibutuhkan benda-benda konkret yang dapat memfasilitasi siswa dalam belajar.

Pembelajaran IPA dapat mencapai tujuannya jika didukung dengan adanya peran aktif siswa dan kekreatifannya seorang pendidik sebagai fasilitator dalam proses belajar. Hal ini sejalan dengan pendapat Martubi (2009) yang mengatakan bahwa pembelajaran adalah sebuah proses yang melibatkan beberapa unsur, diantaranya guru sebagai fasilitator belajar, siswa sebagai subjek belajar dan sarana/prasarana sebagai salah satu fasilitas dalam proses pembelajaran. Namun pada kenyataannya, masih banyak siswa yang belum dapat berperan aktif dalam kegiatan belajar mengajar di kelas. Akibatnya motivasi belajar siswa masih sangat rendah. Salah satu faktor yang menyebabkan ketidakaktifan siswa terhadap proses belajar mengajar di kelas adalah belum adanya media yang tepat, yang dapat memotivasi siswa untuk mengembangakan kreativitas dan kemandirian mereka khususnya pada pembelajaran IPA.

Media pembelajaran sangat diperlukan untuk mata pelajaran IPA tentang siklus air yang mencangkup beberapa tahapan yaitu evaporasi, transpirasi, sublimasi, kondensasi, pengendapan, limpasan, dan infiltrasi. Hal ini sejalan dengan pendapat Arsyad (2006:4) yang mengatakan bahwa media adalah alat yang menyampaikan pesan-pesan pembelajaram. Namun, penerapan media seringkali terabaikan dengan 
berbagai alasan. Keterbatasan waktu, sulit mencari media yang tepat dan biaya yang tidak tersedia sering menjadi alasan dalam pembuatan media pembelajaran. Sebenarnya berbagai alasan tersebut tidak perlu muncul, karena banyak benda-benda disekitar yang dapat dimanfaatkan dan dibuat dengan cara tradisional sebagai media pembelajaran.

\section{Berdasarkan}

wawancara

peneliti dengan guru kelas $\mathrm{V}$ di SDN 02 Druju pada hari Kamis 31 Oktober 2019, terdapat permasalahan terkait dengan proses pembelajaran yaitu kondisi kelas yang kurang kondusif karena siswa bosan saat proses belajar khususnya mata pelajaran IPA. Media yang selama ini digunakan berupa media gambar sehingga menyebabkan proses pembelajaran tidak berjalan maksimal. Terdapat beberapa materi yang perlu diajarkan dengan menggunakan media pembelajaran salah satunya adalah materi siklus air. Guru kelas belum menemukan media yang tepat untuk digunakan dalam menjelaskan materi pembelajaran di kelas.

Salah satu materi pembelajaran yang masih belum ditemukan medianya adalah materi siklus air. Pada materi ini, siswa belum mampu mengurutkan tahapan-tahapan siklus air serta masih kurangnya pemahaman tentang siklus air. Akibatnya, siswa kurang termotivasi dalam mengikuti pembelajaran di kelas dan sulit memahami materi tersebut. Rendahnya motivasi belajar siswa dalam mata pelajaran IPA materi siklus air merupakan masalah bagi guru, dalam hal ini guru diharapkan mampu menciptakan suasana baru yang mampu membangkitkan semangat siswa dalam pembelajaran. Hal ini sesuai dengan penelitian yang dilakukan Risabethe (2015) yang menyatakan bahwa pemahaman guru terhadap kondisi psikologis siswa akan membawa guru untuk mengembangkan media pembelajaran yang dapat meningkatkan motivasi belajarnya.

Berdasarkan permasalahan tersebut, maka perlu dilakukan penelitian mengenai pengembangan media Kosir (kotak siklus air) untuk digunakan dalam menerangkan materi terkait Siklus Air mata pelajaran IPA kelas V Sekolah Dasar. Media Kosir (kotak siklus air) ini dibuat secara tradisional dan dengan bahanbahan yang mudah didapat. Media Kosir (kotak siklus air) ini mempunyai 
keistimewaan tersendiri yaitu kotak yang didalamnya terdapat ilustrasi gambar siklus air beserta tahap-tahap siklus air yang kemudian dapat dibuka dan memiliki tiga dimensi. Media tersebut diharapkan dapat menjadi media pembelajaran yang menarik dan efisien sehingga siswa akan lebih termotivasi serta mudah mempelajari dan memahami pembelajaran IPA khususnya materi siklus air, selain itu juga dapat memberikan inspirasi bagi pendidik sebagai fasilitator agar lebih kreatif dalam penggunaan media.

\section{B. Metode Penelitian}

Metode penelitian yang digunakan adalah penelitian dan pengembangan atau Research and Development (R\&D) dengan menggunakan model pengembangan Borg \& Gall. Penelitian dan pengembangan menurut Borg \& Gall dalam Setyosari (2010: 228) terdiri dari 10 tahapan, namun peneliti hanya menggunakan 8 tahap penelitian hanya menggunakan 8 tahap penelitian dan pengembangan diantaranya penelitian dan pengumpulan informasi awal, perencanaan, pengembangan format produk awal, uji coba awal, revisi produk, uji coba lapangan terbatas, revisi produk kedua dan uji lapangan utama. Penelitian ini dilaksanakan di SDN 02 Druju Sumbermanjing Wetan. Subyek dari penelitian tersebut adalah siswa kelas V SDN 02 Druju. Teknik pengumpulan data menggunakan instrumen tes berupa lembar angket motivasi belajar siswa, lembar kemenarikan media dan menggunakan lembar validasi untuk menguji kevalidan dari media yang telah dikembangkan melalui penilaian oleh ahli media dan materi.

Teknik analisis data yang digunakan ada dua. Teknik pertama digunakan untuk mengetahui kevalidan dari produk yang telah dikembangkan. Adapun pedoman kualitas kevalidan menggunakan klasifikasi interpretasi penilain kevalidan seperti pada Tabel Media KOSIR (Kotak Siklus Air) dikatakan valid jika rata-rata dari validator minimal dalam kategori "baik". Data yang diperoleh kemudian dianalisis menggunakan rumus sebagai berikut:

$\mathrm{P}=\frac{\sum x}{\sum x_{i}} \times 100 \%$

Keterangan:

$\mathrm{P}=$ Presentase

$\sum x=$ Jumlah skor yang diperoleh dari validator

$\sum X_{i}=$ Jumlah skor ideal (Arikunto, 2013:313).

Tabel 1. Kualifikasi Tingkat Kelayakan dari Presentase Rata-Rata

Tingkat Kualifikasi Keterangan
Kelayakan
$(\%)$




\begin{tabular}{ccc}
\hline $81-100$ & $\begin{array}{c}\text { Sangat } \\
\text { baik } \\
\text { Baik }\end{array}$ & $\begin{array}{c}\text { Perlu } \\
\text { direvisi } \\
\text { Perlu } \\
\text { direvisi }\end{array}$ \\
$41-80$ & $\begin{array}{c}\text { Cukup } \\
\text { Kurang } \\
\text { baik } \\
21-40\end{array}$ & $\begin{array}{c}\text { Direvisi } \\
\text { Direvisi }\end{array}$ \\
$0-20$ & $\begin{array}{c}\text { Sangat } \\
\text { kurang }\end{array}$ & Direvisi \\
\hline Teknik & analisis data kedua
\end{tabular}

digunakan untuk mengetahui

keefektivan dari suatu produk yang telah dikembangkan yaitu dengan menggunakan lembar angket motivasi belajar siswa dan lembar kemenarikan media. Teknik analisis yang digunakan adalah menghitung angket motivasi dan angket kemenarikan media. Adapun pedoman kriteria motivasi belajar siswa seperti pada Tabel 2 sebagai berikut:

Rumus untuk menghitung skor angket motivasi belajar siswa

Nilai $(\%)=\frac{\text { jumlah } \text { skor yang diperoleh }}{\text { skor maksimum }} \times 100 \%$

Tabel 2. Kriteria Motivasi Belajar Siswa

\begin{tabular}{cc}
\hline Nilai \% & Kriteria \\
\hline $80-100$ & Minat siswa sangat tinggi \\
$66-79$ & Minat siswa tinggi \\
$56-65$ & Minat siswa cukup tinggi \\
$40-55$ & Minat siswa kurang tinggi \\
\hline (Purwanto, 2009: 207)
\end{tabular}

Adapun pedoman kriteria kemenarikan media seperti Tabel 3 sebagai berikut:

Rumus menghitung skor angket kemenarikan media

Persentase daya tarik media
$\frac{\text { skor perolehan }}{\text { skor maksimum indikator }} \times 100 \%$ Tabel 3. Interpretasi Olah Data Respon Tentang Kemenarikan Media

\begin{tabular}{cc}
\hline Nilai \% & Interprertasi \\
\hline $80-100$ & Sangat menarik \\
$66-79$ & Menarik \\
$56-65$ & Cukup menarik \\
$46-55$ & Kurang menarik \\
$\leq 45$ & Sangat kurang \\
& menarik \\
\hline
\end{tabular}

(Sudjana, 2005)

\section{C.Hasil Penelitian dan Pembahasan}

Produk akhir yang dikembangkan adalah media KOSIR (Kotak Siklus Air) pada materi pokok siklus air dalam Tema 8 (Lingkungan Sahabat Kita) Subtema 1 (Manusia dan Lingkungan) untuk kelas V Sekolah Dasar. Peneliti menggunakan media KOSIR (Kotak Siklus Air) karena dapat digunakan untuk belajar sambil bermain pada anak SD untuk pelajaran IPA materi siklus air dengan tujuan agar siswa dapat termotivasi dalam mengikuti proses pembelajaran.

Ciri khas produk pengembangan adalah media KOSIR (Kotak Siklus Air) yang terbuat dari bahan-bahan tradisional yang dapat diperoleh dengan mudah serta harga yang relatif murah. Media KOSIR (Kotak Siklus Air) berbentuk kotak dengan ukuran $30 \mathrm{~cm} \times 30 \mathrm{~cm} \times 30 \mathrm{~cm}$ dan mempunyai keistimewaan tersendiri yaitu kotak yang dapat dibuka dan didalamnya terdapat ilustrasi gambar siklus air beserta 
proses terjadinya siklus air. Desain gambar pada media KOSIR (Kotak Siklus Air) menggunakan aplikasi Corel Draw.

Hasil akhir produk yang dikembangkan terdapat pada Gambar 1, yaitu sebagai berikut:
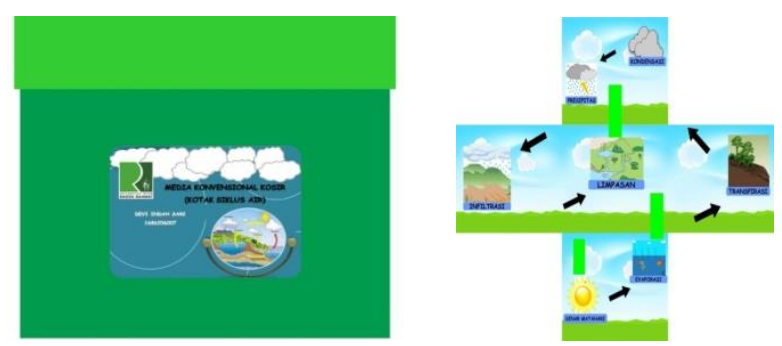

Gambar 1. Hasil Produk Akhir

Produk yang dikembangkan berdasarkan hasil validasi, kritik dan saran perbaikan dari para validator. Validasi media dilakukan sebanyak dua kali yaitu validasi ahli materi dan validasi ahli media. Validasi ini dilakukan untuk menilai produk yang dikembangkan sekaligus memberikan kritik dan saran agar produk yang dikembangkan valid/layak dan efektif digunakan. Setelah produk divalidasi, kemudian dilakukan analisis data kuantitatif dan kualitatif yang diberikan oleh validator. Hasil angket tersebut dijadikan patokan valid/layak untuk media yang dikembangkan. Artinya, media KOSIR (Kotak Siklus Air) sudah layak digunakan sebagai media pembelajaran yang efektif.
Penilaian uji validasi produk untuk ahli materi dilakukan oleh guru wali kelas V SDN 02. Data yang dihasilkan dari validasi ahli materi berupa data kuantitatif dan data kualitatif. Data kuantitatif hasil validasi ahli materi dapat disimpulkan bahwa presentase hitung tingkat pencapaian media pembelajaran yang berupa media KOSIR (Kotak Siklus Air) diperoleh 92\%. Angka tersebut berada dalam kualifikasi sangat baik. Dengan demikian media KOSIR (Kotak Siklus Air) tidak perlu ada revisi. Sedangkan data kualitatif dihimpun dari kritik dan saran ahli materi matapelajaran IPA dalam pernyataan terbuka yang berkenaan dengan media KOSIR (Kotak Siklus Air) materi siklus air terdapat beberapa poin yang perlu diperbaiki.

Penilaian uji validasi produk untuk ahli media dilakukan oleh seseorang yang ahli dalam hal media dan desainnya yaitu dosen dari Prodi Pendidikan Guru Sekolah Dasar Fakultas Psikologi dan IImu. Hasil dari validasi media pembelajaran tersebut diperoleh data kuantitatif dan kualitatif. Data kuantitatif hasil validasi ahli media tersebut dapat disimpulkan bahwa presentase hitung tingkat pencapaian media pembelajaran yang 
berupa media KOSIR (Kotak Siklus Air) diperoleh $92 \%$. Angka tersebut berada pada kualifikasi sangat baik. Dengan demikian media KOSIR (Kotak Siklus Air) tidak perlu revisi. Sedangkan data kualitatif dihimpun dari kritik dan saran ahli media dalam pernyataan terbuka yang berkenaan dengan media KOSIR (Kotak Siklus Air) materi siklus air, akan tetapi validator ahli media tidak menuliskan pernyataan terbuka dikolom saran dan kritik.

\section{Pembahasan}

Uji coba produk dilakukan dengan menggunakan tes berupa soal angket motivasi belajar siswa dengan tujuan untuk mengetahui peningkatan motivasi belajar siswa dari implementasi media KOSIR (Kotak Siklus Air) yang digunakan dalam pembelajaran. Hasil angket motivasi siswa terdapat pada Gambar 2.

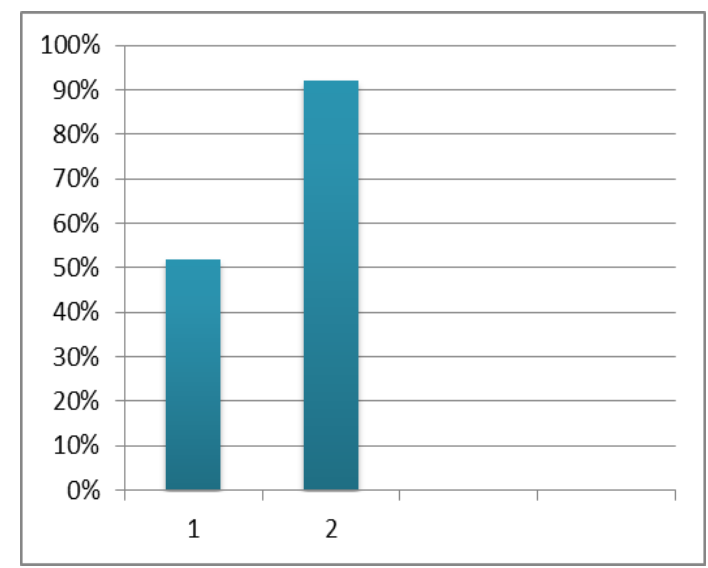

Gambar 2. Grafik Hasil angket motivasi Keterangan:
1: Sebelum menggunakan media KOSIR (Kotak Siklus Air)

2: Sesudah menggunakan media KOSIR (Kotak Siklus Air)

Penggunaan media KOSIR (Kotak Siklus Air) berpengaruh terhadap motivasi belajar siswa kelas V SD. Hal ini dapat dilihat pada diagram hasil motivasi belajar siswa. Sebelum menggunakan media KOSIR (Kotak Siklus Air) diperoleh presentase $52 \%$, sedangkan setelah menggunakan media KOSIR (Kotak Siklus Air) diperoleh presentase 92\%. Jadi dapat disimpulkan bahwa terdapat peningkatan motivasi belajar siswa sebesar $40 \%$ setelah menggunakan media KOSIR (Kotak Siklus Air).

Media pembelajaran KOSIR (Kotak Siklus Air) dapat meningkatkan motivasi belajar siswa karena bentuk dan gambar media pembelajaran KOSIR (Kotak Siklus Air yang menarik. Media pembelajaran KOSIR (Kotak Siklus Air) berbentuk kotak tiga dimensi dengan ukuran $30 \mathrm{~cm} \times 30 \mathrm{~cm}$ $x 30 \mathrm{~cm}$ yang didalamnya terdapat ilustrasi gambar siklus air yang dapat dibuka dan ditutup kembali. Bentuk dan gambar dari media pembelajaran KOSIR (Kotak Siklus Air) yang menarik dapat meningkatkan motivasi belajar siswa serta mempermudah 
siswa dalam mempelajari dan memahami pembelajaran IPA materi siklus air. Hal ini sejalan dengan pernyataan Arsyad (2010: 16-17) yang menjelaskan bahwa fungsi media pembelajaran khususnya media visual dapat terlihat dari tingkat kenikmatan siswa ketika belajar (membaca) teks yang bergambar. Menurut pendapat Sanaky (2009), media gambar dapat meningkatkan emosional dan sikap siswa, misalnya informasi yang menyangkut masalah sosial atau ras. Menurut pendapat Arsyad (2013: 20), melalui penggunaan media gambar siswa dapat lebih mudah memahami dan mengingat informasi atau pesan yang terkandung dalam gambar sehingga dapat mencapai tujuan pembelajaran. Hal ini diperkuat dengan hasil penelitian dari Hayati (2019) yang menyatakan bahwa penggunaan media gambar sangat membantu dalam pembelajaran siswa, hal ini karena gambar adalah salah satu media yang paling efektif dalam pembelajaran.

Media pembelajaran KOSIR (Kotak Siklus Air) dapat meningkatkan motivasi belajar siswa karena digunakan secara berkelompok sehingga siswa mampu bekerja sama dengan baik dalam kelompok. Hal ini terlihat hampir semua anggota mengetahui jawaban dari soal yang dikerjakan. Siswa telah mampu mempresentasikan hasil pekerjaannya menggunakan media pembelajaran KOSIR (Kotak Siklus Air) dengan baik. Banyak siswa yang berani bertanya jawab tentang materi siklus air sehingga sehingga membuat siswa berpartisipasi aktif dalam pembelajaran. Menurut pendapat Harsanto (2007: 44), belajar kelompok dapat meningkatkan kerjasama, partisipasi aktif siswa, kekompakkan dan rasa percaya diri siswa. Hal ini diperkuat dengan hasil penelitian dari Suprapti (2018) yang menyatakan bahwa belajar bersama dalam kelompok menekankan kepada lingkungan belajar untuk bekerja sama dalam mendorong interaksi antar siswa sehingga para siswa akan dapat saling memahami dan saling menghargai satu sama lain.

Media pembelajaran KOSIR (Kotak Siklus Air) dapat meningkatkan motivasi belajar siswa karena penggunaan media membentuk pengalaman langsung siswa. Menurut Yanti (2019), peran motivasi sangat penting dalam pembelajan karena motivasi memberi penguatan belajar 
pada siswa. Siswa tidak hanya mendengarkan materi yang disampaikan peneliti saja, melainkan siswa dapat melihat, menyentuh, merasakan dan mengalami sendiri melalui media pembelajaran KOSIR (Kotak Siklus Air) sehingga membuat siswa lebih memahami materi yang disampaikan dan tidak mudah bosan dalam mengikuti pembelajaran. Hal ini sejalan dengan pernyataan Arsyad (2013: 14) yang mengatakan bahwa hasil belajar diperoleh mulai dari pengalaman langsung (konkret), kenyataan yang ada di lingkungan kehidupan seseorang kemudian melalui benda tiruan, sampai kepada lambang verbal (abstrak). Hal ini diperkuat dengan hasil penelitian dari Ananda (2018) yang menyatakan bahwa melalui pengalaman langsung siswa akan memahami konsepkonsep yang mereka pelajari dan menghubungkannya dengan konsep lain yang telah dipahami.

Hasil penelitian ini juga sesuai dengan penelitian yang dilakukan Kurniawan (2019). Hasil uji kelayakan berdasarkan penilaian dari ahli materi media ini termasuk dalam kategori "baik" dengan skor 3,84. Hasil penilaian ahli media, media ini termasuk dalam kategori baik dengan skor 3,41. Berdasarkan data hasil uji coba terbatas dengan 4 siswa, media ini termasuk dalam kategori baik dengan skor rata-rata 3,67. Berdasarkan hasil uji coba lapangan dengan 8 siswa, media ini termasuk dalam kategori baik dengan skor ratarata 4.03. Kemudian penelitian dan pengembangan yang dilakukan Ningtiyas (2019). Pengembangan media ini dikatakan valid dengan memperoleh tingkat kevalidan dari ahli media sebesar 96, 59\%, dari ahli materi sebesar $97,36 \%$ dan angket responden sebesar $98,14 \%$. Hasil uji coba sebelum menggunakan media dan setelah menggunakan media didapati pertambahan rata-rata sebesar $40,37 \%$.

Kelebihan media KOSIR (kotak siklus air) ini dibuat dari bahan-bahan yang mudah didapat sehingga mempermudah guru dalam pembuatannya. Hal ini sejalan dengan hasil penelitian yang dilakukan oleh Jatmika (2015) yang menyatakan bahwa dalam penggunaan media pembelajaran guru dituntut untuk selalu kreatif memanfaatkannya atau menciptakan media tersebut. Media KOSIR (kotak siklus air) ini mempunyai keistimewaan tersendiri yaitu kotak yang didalamnya terdapat 
ilustrasi gambar siklus air beserta tahap-tahap siklus air yang kemudian dapat dibuka dan memiliki tiga dimensi. Kendala yang dihadapi saat menggunakan Media KOSIR (Kotak Siklus Air) adalah ukuran kotak yang terlalu besar sehingga siswa sulit menempatkan media tersebut dan media tersebut sulit untuk dibawah kemana-mana.

Keunggulan Media KOSIR (Kotak Siklus Air) dari media yang lain adalah Media KOSIR (Kotak Siklus Air) ini berbentuk kotak yang dapat dibuka kemudian ditutup kembali yang tidak dimiliki media lain dan didalamnya sudah terdapat ilustrasi gambar siklus air beserta tahap-tahap siklus air yang dapat digunakan siswa secara berkelompok.

Oleh karena itu, secara umum dapat dikatakan bahwa penggunaan media KOSIR (Kotak Siklua Air) yang sudah dikembangkan dan sudah dimodifikasi pada kegiatan pembelajaran layak digunakan dan dapat meningkatkan motivasi belajar siswa, sehingga akan berdampak baik pada hasil belajar siswa

\section{E. Kesimpulan}

Kelayakan dari media KOSIR (Kotak Siklus Air) dapat dilihat dari hasil penilaian oleh para ahli media dan ahli materi. Rata-rata rekapitulasi penilain dari validator ahli media adalah $92 \%$ berada pada kualifikasi sangat baik. Sedangkan rata-rata rekapitulasi penilaian dari validator ahli materi adalah $93 \%$ berada pada kualifikasi sangat baik. Jadi berdasarkan hasil rekapitulasi penilaian oleh validator media KOSIR (Kotak Siklus Air) sudah layak digunakan.

Keefektivan dari media KOSIR (Kotak Siklus Air) dilihat dari angket motivasi belajar siswa. Hasil angket motivasi belajar siswa pada uji perorangan diperoleh $69 \%$. Hasil angket motivasi belajar siswa pada uji lapangan terbatas sebelum menggunakan media diperoleh $52 \%$ berada pada kualifikasi minat siswa kurang tinggi, sedangakn sesudah menggunakan media KOSIR (Kotak Siklus Air) siswa memperoleh 92\% berada pada kualifikasi minat siswa sangat tinggi. Hal ini dikatakan bahwa motivasi belajar siswa tinggi dan meningkat setelah diberikan media KOSIR (Kotak Siklus Air).

\section{DAFTAR PUSTAKA}

Ananda, Rizki. (2018). Analisis Kemampuan Guru Sekolah Dasar Dalam Implementasi Pembelajaran Tematik di SD. Jurnal Basicedu Research \& 
Learning in Elementary Education, 2(2), 11-12

Arsyad, Azhar. (2006). Media Pembelajaran. Jakarta: PT. Rajagrafindo Persada.

Arsyad, Azhar. (2007). Media Pembelajaran. Jakarta: Raja Grafindo.

Arsyad, Azhar. (2009). Media Pembelajaran. Jakarta: Raja Grafindo Persada Rineka Cipta.

Arsyad, Azhar. (2010). Media Pembelajaran. Jakarata: PT. Raja Grafindo Persada

Arsyad, Azhar. (2013). Media Pembelajaran. Jakarta: Raja Grafindo Persada

Harsanto, Radno. (2007). Pengelolaan Kelas yang Dinamis. Yogyakarta: Kanisiu

Hayati, Nur. (2019). Penerapan Pembelajaran Berbasis Media Gambar Seri Untuk Meningkatkan Keaktifan Materi Mengarang Kelas III. Jurnal PGSD STKIP PGRI Banjarmasin, 1(2), 115-132. Jatmika, Herka Maya. (2005). Pemanfaatan Media Visual dalam Menunjang Pembelajaran Pendidikan Jasmani di Sekolah Dasar. Jurnal Pendidikan Jasmani Indonesia, 3(1), 89-99.

Kurniawan, Candra. (2019). Pengembangan Media Pembelajaran Siklus Air Dan Dampaknya Pada Tema Peristiwa Dalam Kehidupan Untuk Kelas V Sdn Jetis II. Jurnal IImu Pendidikan, 5(2), 611-615

Martubi. (2009). Peningkatan Prestasi Belajar Matematika Lanjut Melalui Pembelajaran Menggunakan Modul dan Lembar Kerja dengan Soal Latihan Berjenjang. Jurnal Pendidikan Teknologi dan Kejuruan, 18(1), 86-102.

Maslichah, Asyari. (2006). Penerapan Sains Teknologi Masyarakat Dalam Pembelajaran Sains di SD.
Jakarta: Depdiknas Dirjen Dikti Direktorat Ketenagaan.

Ningtiyas, Tri Wahyu. (2019). Pengembangan Media POP-UP BOOK Untuk Mata Pelajaran IPA Bab Siklus Air dan Peristiwa Alam Sebagai Penguatan Kognitif Siswa. Jurnal Kajian Teknologi Pendidikan, 2(2), 115-120.

Purwanto. (2009). Evaluasi Hasil Belajar. Yogyakarta : Pustaka Pelajar. hlm. 207.

Ratnaningsih, Sita. (2018). Upaya Meningkatkan Motivasi Belajar Siswa dengan Menggunakan Media Gambar Pada Pembelajaran Tematik di Sekolah Dasar. Jurnal Pendidikan Guru MI, 5(2), 276-284.

Risabethe, Abiy. (2015). Pengembangan Media Pembelajaran untuk Meningktakan Motivasi Belajar dan Karakter Semangat Kebangsaan Siswa Kelas V SD. Jurnal Pendidikan Teknologi dan Kejuruan, 7(1), 34-45.

Sadiman, A. (2003). Media Pendidikan Pengertian,

Pengembangan,

Pemanfaatannya. Jakarta: Rajawali Pers.

Sanaky, A. H, Hujair. (2009). Media Pembelajaran. Yogyakarta: Safiria Insania Press.

Setyosari, P. (2010) Metode Penelitian Pendidikan dan Pengembangan. Jakarta: Kencana HIm 228

Sudjana, Nana. (2013). Dasar-Dasar Proses Belajar Mengajar. Bandung: Sinar Baru Algensindo.

Sudjana, N, A. Rivai. (2005). Media Pengajaran: Penggunaan dan Pembuatannya. Bandung: Sinar Baru.

Suprapti. (2018). Belajar Kelompok Pada Mata Pelajaran IPS di Kels VI Sekolah Dasar. Jurnal Bidang 
Pendidikan Dasar (JBPD), 2(1), 48-56

Suwastono. (2011). Pembelajaran ELearning Berbasis Moodle pada Mata Kuliah Penginderaan Jauh S-1 Jurusan Geografi Universitas Negeri Malang. Malang: PPS UM

Yanti, Yulia Eka. (2019). Analisis Motivasi Belajar Mahasiswa Calon Guru Sekolah Dasar (PGSD) Pada Mata Kuliah Konsep Dasar IPA. Jurnal PGSD STKIP PGRI Banjarmasin, 1(2), 96-103 